\title{
Influences of Teaching Styles and Motor Educability on Learning Outcomes of Volleyball
}

\author{
Syamsuddin 1 \\ ${ }^{1}$ Faculty of Sports Science, Universitas Negeri Jakarta, Jakarta, Indonesia \\ Correspondence: Syamsuddin, Faculty of Sports Science, Universitas Negeri Jakarta, Kampus B, Jl. Pemuda 10, \\ Rawamangun, Jakarta 13220, Indonesia. E-mail: samsudin@unj.ac.id
}

Received: January 16, 2014

doi:10.5539/ass.v10n5p109
Accepted: February 20, 2014 Online Published: February 28, 2014

URL: http://dx.doi.org/10.5539/ass.v10n5p109

\begin{abstract}
This research aims to look at the influence of teaching styles and motor educability on the learning outcomes of volleyball. This research uses the $2 \times 2$ factorial design. Generally, practice-teaching styles influence the learning outcomes of volleyball game more than the teaching styles of inclusion. For students who have a high motor educability, learning outcomes of volleyball through application of a practice style is better as compared to an inclusion style. There is an interaction between the teaching styles and motor educability in the learning outcomes of volleyball game as indicated among the students.
\end{abstract}

Keywords: teaching style, practice-teaching style, inclusion teaching style, and motor educability

\section{Introduction}

Under Acts No. 20 of 2003 in the National Education System, education is a series of: planned and aware attempts of presenting the learning atmosphere and learning process so that the educated participants are active to develop their potential to possess the spiritual power, self control, personality, intelligence, morality as well as skills for the needs of individual himself the society, nation and state. (Department of Education and Culture on National Education System Acts No. 20 of 2003). From aforementioned education formula, it is clear that education has a great responsibility towards the nation and state. Education is hoped to increase the capabilities, life quality and dignity of the nation.

University student is obliged to master basic techniques in volleyball within one semester. In fourteen face-to-face meetings, presentation of volleyball basic techniques ranges only from twelve to fourteen times. Lecturer's duty in teaching-learning process is to decide and to select appropriate teaching styles. Therefore, teaching volleyball basic techniques requires the selection of teaching styles appropriate and easily applied to the students, so that volleyball basic techniques can be mastered well and correctly. Teaching styles are the inclusion teaching style and practice-teaching style specifically to teach basic techniques in volleyball (Mosston \& Ashworth, 1986).

Teaching the basic techniques of volleyball also needs motor educability in a volleyball game. Motor educability of a volleyball game is student's basic capabilities of mastering the basics in a volleyball game. It is well known that basic technique in volleyball requires good motor abilities in order to do it.

Therefore, the success in learning volleyball basic techniques, beside determined by lecturer's capabilities to apply appropriate teaching styles, is also determined by the student's motor educability. This research thus aims to find the influence of teaching styles and motor educability on the success of teaching and learning the basic techniques of volleyball.

\section{Theoretical Foundation}

\subsection{Learning Outcomes of Volleyball-Game}

A variety of opinions as well as viewpoints is provided by educational experts on significance of "learning" and "learning outcomes". Basically the similarity is as follow: (1) learning is a change existing in individual implementing the learning; (2) learning outcome is individual capability after undergoing a learning process, including cognitive, affective and psychomotor learning. A learning is an attempt done by a person to change a, as a result of his or her experience in the interaction with his or her environment (Slameto, 1995). 
Gagne is known for the "four categories of learning outcomes" or "Four Major Categories of Learning Capabilities" specifically paying attention on learning outcomes. The four categories are: (1) intellectual skill, namely capability to turn a person to be competent in a subject so that he or she could classify, identify, and generalize a symptom; (2) cognitive strategy, namely capability to control his or her intellectual activities in handling the problems; (3) verbal information, namely a person's capability to use verbal or writing language in expressing a problem; (4) motor skill, namely a person's ability to coordinate muscle movement. Whereas Hasibuan (1994) stated that learning outcome is a presentation of existing change in cognitive domain, namely from not knowing turns into knowing or understanding. Learning outcome in the psychomotor domain means from not being able to do a movement skill to being able to be involved actively.

\subsection{Teaching Styles}

Teaching strategies is the ability to use a variety of informational distribution methods tostudents through a variety of media and by composing practice experiences basically centered on the teacher, based on invention and independence. Mosston (1994) said that learning strategy is like a war strategy, that is one way of maneuvering learning system of volleyball game, so that objective of the learning process can be achieved effectively and efficiently. Learning spectrum is a theoretical conception as well as design, implemented from teaching styles selected by the teacher.

An inclusion teaching style is teaching guideline used by a lecturer presenting a material detailing in its difficulty level. The objective for this teaching style is for the students to be creative and could facilitate learning a motor skill, because students are given the freedom to select and determine how many time they will rehearse their movement task.

A practice-teaching style is a teaching guideline utilized by lecturer to present teaching material in a practice form part-by-part consecutively. The important element is that the teacher teach every part of the teaching materials consecutively and the student is given a sufficient time to practice repetitively. Thus, teaching and rehearsing are the elements which determines the student to study through practice-teaching style.

\subsection{Motor Educability}

Motor educability is the capacity obtained from a general motor skill underlining a good presentation level. This fundamental motor ability is determined by genetic factor, and stimulation from environment which is introduced early. Concept of General Motor Ability (GMA) and General Motor Educability (GME) is included in Intelligence Quotient (IQ). This means that Motor Educability is the ability to learn motor skills easily and quickly (Mc Cloy \& Young, 1984). Thus, the relevance between ability of students in learning a new motor skill with a degree of motor educability is similar to the interrelation between student's intelligence and his success in learning the subject materials.

What it means with ability to learn a new motor skill is "the ease of a person in learning new skills also refers to as motor educability" (Matthews, 1983). The quality of motor educability is the ability to learn motor skills easily and well (Baumngartner \& Jackson, 1995). In other word, motor educability is the general ability to learn a task immediately and precisely (Rusli Lutan, 1988). In this research motor educability is categorized into two , namely high motor educability and low motor educability. This motor educability is hoped to interact with other variables to increase learning outcomes of volleyball games.

\subsection{Research Hypothesis}

\subsubsection{Difference between Inclusion-Teaching Style and Practice-Teaching Style in Overall Learning Outcomes of} Volleyball Games

In inclusion-teaching style, students is given the freedom to select and to change teaching materials. Students are mentally and physically prepared to learn volleyball basic technique and has the freedom to select material at a difficulty level which suits them, will add self-confidence to master the basic techniques in volleyball. The number of practices during each meeting is not limited, to provide chances for students to rehearse the basic technique as much as possible. Therefore, with numerous practices, volleyball basic technique will be easily mastered, and feedback provided individually at the end of each meeting will help students to rectify and correct their mistakes. Furthermore, students have sufficient time to analyze and improve basic technique before the next meeting.

In practice-teaching style, students learn the materials determined by lecturer, and imitate movement shown by the lecturer. The teaching process occurring in this style does not develops the student's creativity, since students only do assignments ordered by the lecturer whose teaches a technique part by part. The number of practices for each part of volleyball basic techniques in each meeting is determined by the lecturer. Feedback provided by 
lecturer in groups during the learning process, can contribute to positive and negative effects. For students, feedback given for mistakes done in the movement will improve their mistakes.

Therefore it is assumed that learning outcomes of volleyball basic technique with inclusion-teaching style is better as compared to practice-teaching style.

2.4.2 Difference between Inclusion-Teaching Style with Practice-Teaching Style on Learning Outcomes of Volleyball Game for Students with High Motor Educability

In inclusion-teaching style, students with high motor educability, their motor learning program is through the lecturer's explanation and through assignment sheets. Students already has the idea of executing the correct volleyball basic technique, therefore the information on the assignment sheets serves as a guideline.

For students with high motor educability, and having completed theoretical mastery of volleyball basic technique, this will enable them to study volleyball basic technique easily. Students are free to select subject matters, practice as many times as possible and feedback is given individually at the end of each meeting. This will further enhances the mastery in volleyball basic technique for students with high motor educability.

On the other hand, students with high motor educability which uses practice-teaching style, theoretically has not master the correct volleyball basic technique. For this group, lecturers will teach and demonstrate the basic techniques using part by part approach.

Therefore it is assumed that learning outcomes of volleyball basic technique by using inclusion-teaching style is better as compared to practice-teaching style for students with high motor educability.

2.4.3 Difference between Inclusion-Teaching Style with Practice-Teaching Style on Learning Outcomes of Volleyball for Students with Low Motor Educability

In the practice-teaching style, motor learning program of volleyball basic techniques for students is arranged successively part-by-part. Thus, this step-by-step approach will help the students master the correct volleyball basic technique.

Explanation and demonstration done by the lecturer to teach the technique is presented part-by-part, combined with the number of practices determined by the lecturer as well as group feedback will help the students to master the volleyball basic technique, since student with low motor educability needs guidance.

Whereas for students with low motor educability, using the inclusion-teaching style will be difficult to master by the students. Having motor educability as basic ability is important besides the need to learn volleyball basic techniques in the form of cognitive ability, associative, and automation.

Therefore, it is assumed that the learning outcomes of volleyball basic technique using practice-teaching style is better than inclusion-teaching style for students with low motor educability.

\subsubsection{Interaction between Teaching Style with Motor Educability on Learning Outcomes of Volleyball Game}

A teaching style is a guideline used by a teacher or a lecturer to teach basic skills and technique. The teaching guideline is applied with the objective that volleyball basic techniques can be mastered correctly by students. The teaching style is classified in accordance with its implementation, namely, inclusion-teaching style and practice-teaching style. Both teaching styles will benefit and can be successfully used to teach volleyball basic technique.

Student needs good motor educability with the existing specific motor skills on volleyball basic techniques. Every student has their own level of motor educability and to benefit from this, appropriate teaching style are needed in order to succeed in learning volleyball basic technique. Therefore, it is assumed that there is interaction between teaching style and motor educability toward learning outcomes of volleyball basic technique.

\section{Methodology}

Target population in this research are first year Physical Education and Health students at Universitas Negeri Jakarta. Forty students were selected using simple random to represent the population. The sample were then divided into two groups, the Inclusion-Teaching Style (A1) and the Practice-Teaching Style (A2).Both groups (A1) and (A2) were then given motor educability test. Results from each group is compiled according to the obtained scores, from highest to lowest levels, followed by calculating the average scores (X).The formula by Verducci (1980) were used to identify students with high and low motor educability. In each group top 10 students who score high on motor educability test were selected for the high motor educability group and the lowest 10 were selected to be in the low motor educability group. After intervention has taken place, learning outcomes were gathered from each subgroup namely. 


\section{Results}

\subsection{Normality and Homogeneity of the Sample}

Before conducting further testing, the normality and homogeneity of the sample is determined. The outcome of the normality-test of each group showed that the sample is normally distributed.

Bartlett test was used to determine the homogeneity of the variants in this research and results showed that the samples in both the main group and sub-groups are homogenous..

Table 1 shows the descriptive statistics for the samples studied while Table 2 gives the result of the analysis of variance.

Table 1. Descriptive statistic of the sample

\begin{tabular}{ccccc}
\hline \multirow{2}{*}{ Motor Educability } & \multirow{2}{*}{ Statistic } & \multicolumn{2}{c}{ Teaching Style } & \multirow{2}{*}{ Total } \\
\hline High & $n$ & 10 & 10 & 20 \\
& $\bar{X}$ & 77.6 & 69.5 & 73.55 \\
& $\sum X$ & 776 & 695 & 1471 \\
& $\sum X^{2}$ & 60424 & 48709 & 109133 \\
\multirow{2}{*}{ Low } & $S D$ & 4.79 & 6.72 & 7.04 \\
& $n$ & 10 & 10 & 20 \\
& $\bar{X}$ & 60 & 75.4 & 67.7 \\
& $\sum X$ & 600 & 754 & 1354 \\
& $\sum X^{2}$ & 36152 & 57196 & 93348 \\
& $S D$ & 4.11 & 6.19 & 9.41 \\
& $n$ & 20 & 20 & 40 \\
& $\bar{X}$ & 68.8 & 72.45 & 70.63 \\
& $\sum X$ & 1376 & 1449 & 2825 \\
& $\sum X^{2}$ & 96576 & 105905 & 202481 \\
& $S D$ & 10.02 & 6.98 & 8.72 \\
\hline
\end{tabular}

Table 2. Result of ANOVA

\begin{tabular}{ccccc}
\hline Source & df & Sum of Squares & Mean Square & F \\
\hline Teaching Style & 1 & 133.23 & 133.2 & $4.32^{*}$ \\
Motor Educability & 1 & 342.23 & 342.2 & $11.11^{* *}$ \\
Interaction & 1 & 1380.63 & 1381 & $44.81^{* *}$ \\
Error & 36 & 1109.30 & 30.81 & \\
Total & 39 & 2965.38 & & \\
\hline
\end{tabular}

$* \mathrm{p}<0.05 * * \mathrm{p}<0.01$

Result of data analysis shows that the average learning outcome of volleyball game is 72.45 with standard deviation of 6.98. Analysis of variants to test the hypothesis on the difference in inclusion and practice-teaching styles toward learning outcome of volleyball basic techniques is significant $(F=4.32, p<0.05$. Therefore the null hypothesis is rejected and it can be concluded that there is a significant difference between inclusion-teaching style with practice-teaching style toward learning outcome of volleyball basic techniques.

Data analysis motor educability also shows significant difference between high motor educability and low motor educability $(\mathrm{F}=11.11, \mathrm{p}<0.01)$. Interaction between teaching styles and motor educability also proves to be significant $(\mathrm{F}=44.81, \mathrm{p}<0.01)$. 


\section{Conclusion}

Based on data analysis it is concluded that:

1) Overall, learning outcome of volleyball by using practice-teaching style is higher as compared to inclusion-teaching style. In other words, it is concluded that the influence of inclusion teaching style is better, as compared to practice-teaching style toward learning outcome of volleyball for student with high motor educability.

2) For students with high motor educability, the learning outcome of volleyball with inclusion-teaching style is better as compared to practice-teaching style. In other words, it is concluded that the influence of inclusion-teaching style is better, compared to practice-teaching on learning outcome of volleyball for student with high motor educability style.

3) For students with low motor educability, the influence of practice teaching style on learning outcome of volleyball is better as compared to inclusion style. In other words, it is concluded that the influence of practice teaching style is better, compared to inclusion teaching style on learning outcome of volleyball for university student with low motor educability.

4) There is interaction of teaching style with motor educability on learning outcome of volleyball to the student. In other words, the application of inclusion teaching style is better for students with high motor educability , whereas the application of practice teaching style is better for students with low motor educability.

\section{References}

Baumngartner, T. A., \& Jackson, A. S. (1995). Measurement to Evaluation in physical Education and Exercise Science. Iowa: Brown \& Benchmark Publisher.

Ferducci, F. M. (1980). Measurement Concepts in Physical Education. St. Louis. The C.V. Mosby Company.

Hasibuan, J. J. (1994). Proses Belajar Mengajar Keterampilan Dasar Pengajaran Mikro. Bandung: Remaja Rosdakarya.

Lutan, R. (1998). Belajar Keterampilan Motorik Teori dan Metode. Jakarta: Dikti, P2LPTK.

Mathews, D. K. (1983). Measurement In Physical, Second edition. Philadelphia: WB Saunders Company.

Mc. Cloy, C. H., \& Young, N. D. (1984). Test and Measurement in Health and Physical education. New York: Appleton Century Crofts Inc.

Mosston, M., \& Asworth, S. (1986). Teaching Physical Education. Columbus: Marril Publishing Company.

Slameto. (1995). Belajar dan Faktor-faktor yang Mempengaruhinya. Jakarta: PT. Rineka Cipta.

Undang-Undang Republik Indonesia No. 20 Tahun 2003 tentang Sistem Pendidikan Nasional. Jakarta: BP Cipta Jaya, 2003.

\section{Copyrights}

Copyright for this article is retained by the author(s), with first publication rights granted to the journal.

This is an open-access article distributed under the terms and conditions of the Creative Commons Attribution license (http://creativecommons.org/licenses/by/3.0/). 